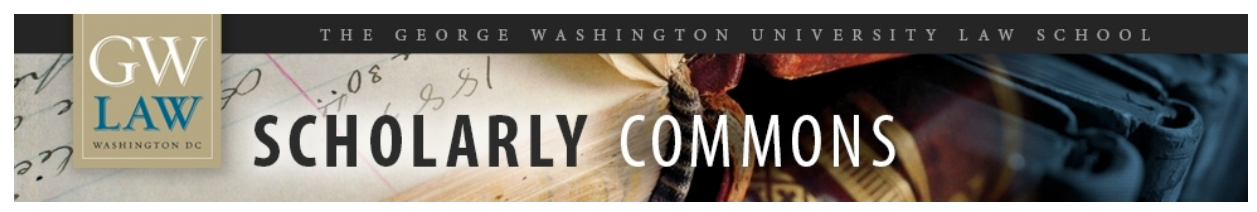

\title{
Crimes Against Humanity and Other Topics: The Sixty-Ninth Session of the International Law Commission
}

\author{
Sean D. Murphy \\ George Washington University Law School, smurphy@law.gwu.edu
}

Follow this and additional works at: https://scholarship.law.gwu.edu/faculty_publications

Part of the Law Commons

\section{Recommended Citation}

Suggested citation: Murphy, Sean D., Crimes against Humanity and Other Topics: The Sixty-Ninth Session of the International Law Commission, American Journal of International Law (forthcoming October 2017).

This Article is brought to you for free and open access by the Faculty Scholarship at Scholarly Commons. It has been accepted for inclusion in GW Law Faculty Publications \& Other Works by an authorized administrator of Scholarly Commons. For more information, please contact spagel@law.gwu.edu. 


\title{
CURRENT DEVELOPMENTS
}

\author{
CRIMES AGAINST HUMANITY AND OTHER TOPICS: \\ THE SIXTY-NINTH SESSION OF THE INTERNATIONAL LAW COMMISSION
}

By Sean D. Murphy*

The International Law Commission held its sixty-ninth session in Geneva from May 1 to June 2, and from July 3 to August 4, 2017, under the chairmanship of Georg Nolte (Germany). ${ }^{1}$ This session was the first of a new quinquennium of the Commission, consisting of members who will serve from 2017 until 2021. Notably, the Commission completed on first reading a full set of draft articles with commentary on crimes against humanity. Progress was also made in developing draft guidelines on the provisional application of treaties; draft guidelines on protection of the atmosphere; draft articles on the immunity of state officials from foreign criminal jurisdiction; and draft conclusions on peremptory norms of general international law (jus cogens).

The Commission did not make any significant progress with respect to its topic on protection of the environment in relation to armed conflicts, but did appoint a new special rapporteur to carry the work forward. Further, the Commission added a new topic to its agenda on succession of states in respect of state responsibility, and added two new topics to its longterm work program, namely on general principles of law and on evidence before international courts and tribunals. The Commission did not work on two topics that completed their first readings in 2016 and that, after receiving reactions from governments and others, will likely undergo their second readings in 2018: identification of customary international law; and subsequent agreements and subsequent practice in relation to the interpretation of treaties.

\section{CRIMES AGAINST HUMANITY}

The Commission commenced work on the topic of crimes against humanity in 2014, appointing Sean D. Murphy (United States; the present author) as special rapporteur. ${ }^{2}$ The syllabus for the topic provides that the objective is "to draft articles for what would become a Convention on the Prevention and Punishment of Crimes against Humanity." ${ }^{33}$ At the sixty-

\footnotetext{
* Manatt/Ahn Professor of International Law, George Washington University, and member of the UN International Law Commission. My thanks to Marta Bylica (JD '18) and Elle Ross (JD '18) for assistance in preparing this essay. ${ }^{1}$ See Report of the International Law Commission on the Work of Its Sixty-Ninth Session, UN GAOR, 72nd Sess., Supp. No. 10, at 2, para. 3 UN Doc. A/72/10 (Sept. 11, 2017) [hereinafter 2017 Report]. This report and other ILC documents are available online at http://legal.un.org/ilc. In addition, UN documents are generally available online at https://documents.un.org/prod/ods.nsf/home.xsp.

${ }^{2}$ Report of the International Law Commission on the Work of Its Sixty-Sixth Session, UN GAOR, 69th Sess., Supp. No. 10, at 265, para. 266, UN Doc. A/69/10 (2014). For discussion of prior work on these draft articles, see Sean D. Murphy, Identification of Customary International Law and Other Topics: The Sixty-Seventh Session of the International Law Commission, 109 AJIL 822, 835-36 (2015) [hereinafter Murphy, Sixty-Seventh Session]; Sean D. Murphy, Protection of Persons in the Event of Disasters and Other Topics: The Sixty-Eighth Session of the International Law Commission, 110 AJIL 718, 727-29 (2016) [hereinafter Murphy, Sixty-Eighth Session].

${ }^{3}$ See Report of the International Law Commission on the Work of Its Sixty-Fifth Session, UN GAOR, 68th Sess., Supp. No. 10, at 140, para. 3 (Annex B), UN Doc. A/68/10 (2013).
} 
seventh session, the Commission provisionally adopted four draft articles with commentary. ${ }^{4}$ At the sixty-eighth session, the Commission provisionally adopted an additional six draft articles with commentaries. ${ }^{5}$ At the sixty-ninth session, the Commission debated the special rapporteur's third report, ${ }^{6}$ ultimately adopting, as discussed below, a draft preamble, five more draft articles, one additional paragraph for a previously-adopted draft article, and a draft annex.

The draft preamble ${ }^{7}$ contains various elements that suggest the motivation for the overall project and that foreshadow the principal objectives within the draft articles of prevention and punishment. The first three preambular paragraphs recognize the fact that, throughout history, persons have been victims of crimes that "deeply shock the conscience of humanity," that such crimes "threaten the peace, security and well-being of the world," and that the prohibition of such crimes is jus cogens. The fourth paragraph speaks to the need for prevention of crimes against humanity, while the fifth paragraph indicates that one part of prevention is putting "an end to impunity for the perpetrators" of such crimes. The sixth paragraph draws attention to the definition of crimes against humanity set forth in draft article 7 of the Rome Statute, ${ }^{8}$ which is the definition adopted for the draft articles themselves, while the seventh paragraph recalls the duty of states to exercise jurisdiction over such crimes. The eighth paragraph speaks to the need for inter-state cooperation, including with respect to extradition and mutual legal assistance. The final paragraph notes the rights of victims and witnesses, but also the right of alleged offenders to fair treatment.

Draft Article $5^{9}$ sets forth a non-refoulement obligation, providing that "[n]o State shall expel, return (refouler), surrender or extradite a person to territory under the jurisdiction of another State where there are substantial grounds for believing that he or she would be in danger of being subjected to a crime against humanity." This draft article was located just after draft article 4, which concerns prevention of crimes against humanity generally, due to a belief that the principle of non-refoulement is preventive in nature. That principle was incorporated in various treaties during the twentieth century, including the 1949 Fourth Geneva Convention, ${ }^{10}$ but is most commonly associated with international refugee law and, in particular, with article 33 of the 1951 Convention Relating to the Status of Refugees. ${ }^{11}$ The Commission did not include in draft article 5 any exception (such as exists in the 1951 Convention) that would enable a state to

\footnotetext{
${ }^{4}$ Report of the International Law Commission on the Work of Its Sixty-Seventh Session, UN GAOR, 70th Sess., Supp. No. 10, at 49-50, paras. 113-14, UN Doc. A/70/10 (2015).

${ }^{5}$ Report of the International Law Commission on the Work of Its Sixty-Eighth Session, UN GAOR, 71st Sess., Supp. No. 10, at 242, paras. 82-83, UN Doc. A/71/10 (Sept. 19, 2016) [hereinafter 2016 Report].

${ }^{6}$ International Law Commission, Third Report on Crimes Against Humanity, UN Doc. A/CN.4/704* (Jan. 23, 2017) (prepared by Special Rapporteur Sean Murphy) [hereinafter Third Report on Crimes Against Humanity].

72017 Report, supra note 1, at 20.

${ }^{8}$ Rome Statute of the International Criminal Court, Art. 7, July 17, 1998, 2187 UNTS 90.

92017 Report, supra note 1, at 12. In 2017, the Commission renumbered some of the previously-adopted draft articles, resulting in a new set of numbering. An earlier number associated with a draft article is indicated in square brackets. Thus, draft article 5 adopted in 2017 resulted in the prior draft article 5 (adopted in 2016) being renumbered as draft article 6[5].

${ }^{10}$ Geneva Convention [No. IV] Relative to the Protection of Civilian Persons in Time of War, Art. 45, Aug. 12, 1949, 6 UST 3516, 75 UNTS 287.

${ }^{11}$ Convention Relating to the Status of Refugees (Geneva, 28 July 1951), 189 UNTS 137, art. 33, para. 1 ("No Contracting State shall expel or return ("refouler") a refugee in any manner whatsoever to the frontiers of territories where his life or freedom would be threatened on account of his race, religion, nationality, membership of a particular social group or political opinion.”).
} 
return the person if he or she has committed a crime or presented a serious security risk. ${ }^{12}$ Rather, the Commission followed the approach taken in more recent treaties, such as the 2006 International Convention for the Protection of All Persons from Enforced Disappearance, ${ }^{13}$ which includes no such exception.

Draft Article $12^{14}$ addresses issues concerning victims, witnesses and others. Paragraph 1 obliges each state to ensure that "any person who alleges that acts constituting crimes that have been or are being committed has the right to complain to the competent authorities," and further that such "complainants, victims, witnesses, and their relatives and representatives," as well as certain other persons, "shall be protected against ill treatment or intimidation" as a result of their cooperation with such authorities. Paragraph 2 provides that each state "shall, in accordance with its national law, enable the views and concerns of victims to be presented and considered at appropriate stages of criminal proceedings against alleged offenders." Paragraph 3 addresses reparations and provides:

Each State shall take the necessary measures to ensure in its legal system that the victims of a crime against humanity have the right to obtain reparation for material and moral damages, on an individual or collective basis, consisting, as appropriate, of one or more of the following or other forms: restitution; compensation; satisfaction; rehabilitation; cessation and guarantees of non-repetition.

The commentary to this paragraph indicates that such "wording acknowledges that States must have flexibility to determine the appropriate form of reparation, recognizing that, in the aftermath of crimes against humanity, various scenarios may arise and reparations must be tailored to the specific context."15

Draft articles 13 and 14 focus on especially important areas of inter-state cooperation with respect to the punishment of crimes against humanity. Draft article $13^{16}$ addresses extradition, building upon the basic provisions contained in the Convention against Torture ${ }^{17}$ and the Convention on Enforced Disappearance, ${ }^{18}$ but with an eye to the very detailed extradition provisions contained in Article 44 of the UN Convention Against Corruption. ${ }^{19}$ In doing so, the Commission explained:

Although a crime against humanity by its nature is quite different from a crime of corruption, the issues arising in the context of extradition are largely the same regardless

\footnotetext{
${ }^{12}$ Convention Relating to the Status of Refugees, art. 33, para. 2.

${ }^{13}$ International Convention for the Protection of All Persons from Enforced Disappearance, Dec. 20, 2006,2716 UNTS 3, art. 16 [hereinafter Enforced Disappearance Convention].

${ }^{14} 2017$ Report, supra note 1, at 15.

152017 Report, supra note 1, at 95, para. (19).

162017 Report, supra note 1, at 15-16.

${ }^{17}$ Convention Against Torture and Other Cruel, Inhuman or Degrading Treatment or Punishment, Art. 8, Dec. 10, 1984, S. TREATY Doc. No. 100-20 (1988), 1465 UNTS 85 [hereinafter Convention against Torture]. Article 8 contains just 4 paragraphs, as compared with the 18 paragraphs of the UN Convention against Corruption.

${ }^{18}$ Convention on Enforced Disappearance, art. 13. Article 13 contains 7 paragraphs.

${ }^{19}$ UN Convention Against Corruption, Art. 44, Oct. 31, 2003, 2349 UNTS 41. Article 44 largely replicates provisions contained in Article 16 of the UN Convention on Transnational Organized Crime, Nov. 15, 2000, 2225 UNTS 209.
} 
of the nature of the underlying crime, and the Commission was of the view that article 44 provides ample guidance as to all relevant rights, obligations and procedures for extradition in the context of crimes against humanity. Moreover, the provisions of article 44 are well understood by the 181 States parties to the 2003 United Nations Convention against Corruption, especially through the detailed guides and other resources developed by the United Nations Office on Drugs and Crime. ${ }^{20}$

The draft articles themselves contain no obligation to extradite an alleged offender. If an alleged offender is present in territory under a state's jurisdiction, the obligation (contained in draft article 10) is for that state to submit the case to its competent authorities for the purpose of prosecution, unless the person is extradited or surrendered to another state or competent international tribunal. Consequently, the purpose of draft article 13 is simply to create circumstances favorable to extradition if a state decides to extradite the person to another state. It does so by addressing different scenarios that may exist as between the two states in question.

Under draft article 13, if the two states have a general extradition treaty between them, the offenses identified in the draft articles are to be regarded as extraditable offenses under that treaty. ${ }^{21}$ If the two states do not have such a treaty, and yet the extraditing state requires a treaty to be in place for the extradition to proceed, then that state "may" (but is not required) to use the draft articles for that purpose. ${ }^{22}$ Indeed, a state that requires that a treaty be in place before an extradition may proceed is obligated to inform the U.N. Secretary-General as to whether it will use the draft articles for this purpose; if it does not intend to do so, then it shall "seek, where appropriate, to conclude treaties on extradition with other States" for this purpose. ${ }^{23}$ If the extraditing state does not require that a treaty be in place before an extradition may proceed, it shall recognize the offenses identified in the draft articles as extraditable offenses ${ }^{24}$ Regardless of whether a treaty is or is not required for the extradition to proceed, an offense covered by the draft articles shall not be regarded as "political offense.",25

Further, draft article 13 makes clear that the extradition is subject to the conditions provided for by the law of the extraditing state, ${ }^{26}$ which includes procedural steps such as certification by a court or government minister. If the national law only allows for extradition to the place where the crime occurred, however, draft article 13 provides that certain other states (such as the state of nationality of the alleged offender) shall be treated as if the crime had been committed in that state. ${ }^{27}$

As indicated above, a state is not obligated to extradite an alleged offender and may always refuse, provided it then submits the case to its own authorities for the purpose of prosecution (or surrenders the person to an international tribunal). Draft article 13, however, addresses some aspects of a refusal to extradite. First, before refusing to extradite, the state

${ }^{20} 2017$ Report, supra note 1, at 100-01, p. 5.

${ }^{21}$ Draft article 13, para. 1.

${ }^{22} I d$. at para. 3.

${ }^{23} I d$. at para. 4.

${ }^{24} I d$. at para. 5.

${ }^{25} \mathrm{Id}$. at para. 2.

${ }^{26} I d$. at para. 6.

${ }^{27} \mathrm{Id}$. at para. 7 
"shall, where appropriate, consult with the requesting State to provide it with ample opportunity to present its opinions...." 28 Second, if the extradition is sought not for the purpose of prosecution but for enforcing a sentence, and the refusal to extradite is because the person is a national of the requested state, then that state should consider enforcing the sentence itself. ${ }^{29}$ Finally, draft article 13 reinforces that nothing in the draft articles obligates a state

to extradite if the requested State has substantial grounds for believing that the request has been made for the purpose of prosecuting or punishing a person on account of that person's gender, race, religion, nationality, ethnic origin, culture, membership of a particular social group, political opinions or other grounds that are universally recognized as impermissible under international law.... ${ }^{30}$

Draft article $14^{31}$ and the draft annex ${ }^{32}$ address a request by one state for mutual legal assistance from another state for investigations, prosecutions and judicial proceedings in relation to crimes against humanity. If a general mutual legal assistance treaty already exists between the requesting and requested states, then that treaty applies to the request for mutual legal assistance, but the provisions of draft article 14 additionally apply if they "provide for greater mutual legal assistance." 33 Those provisions speak, among other things, to overall cooperation on such requests, ${ }^{34}$ to the types of requests that may be made (such as for help in identifying and locating alleged offenders), ${ }^{35}$ and to the possibility of the transmitting of information even in the absence of a request. ${ }^{36}$ If there is no general mutual legal assistance treaty in force between the two states, then the draft annex - a "mini-mutual legal assistance treaty" - applies. The draft annex contains detailed provisions on the designation of a central authority, ${ }^{37}$ procedures for making a request, ${ }^{38}$ the response to the request, ${ }^{39}$ the use of information received by the requesting state, ${ }^{40}$ testimony of persons who come from the requested state, ${ }^{41}$ and costs. ${ }^{42}$

Draft article $15^{43}$ concerns inter-state dispute settlement. Under paragraph 1, states are obligated to endeavor to peacefully settle their disputes. If they cannot do so, paragraph 2 provides:

Any dispute between two or more States concerning the interpretation or application of the present draft articles that is not settled through negotiation shall, at the request of one

\footnotetext{
${ }^{28} I d$. at para. 10 .

${ }^{29} I d$. at para. 8.

${ }^{30} I d$. at para. 9.

312017 Report, supra note 1, at 16-17.

32 Id. at $18-20$.

${ }^{33}$ Draft article 14, para. 7.

${ }^{34} I d$. at paras. 1 (with respect to natural persons), 2 (with respect to legal persons).

${ }^{35} \mathrm{Id}$. at para. 3.

${ }^{36} I d$. at para. 6.

${ }^{37}$ Draft annex, para. 1.

${ }^{38} \mathrm{Id}$. at paras. $3-5$.

${ }^{39} I d$. at paras. 6-12.

${ }^{40} I d$. at paras. 13-14.

${ }^{41} \mathrm{Id}$. at paras. $15-16$ (persons not in detention in the requested state), paras. 17-19 (persons in detention).

${ }^{42} I d$. at para. 20.

432017 Report, supra note 1, at 17-18.
} 
of those States, be submitted to the International Court of Justice, unless those States agree to submit the dispute to arbitration.

If such a compromissory clause is used in a new convention, it would be the first time since 2006 that a global treaty provides for compulsory dispute settlement at the International Court. ${ }^{44}$ The Commission considered whether to require that states first attempt arbitration, an approach taken in many conventions that contain compulsory dispute settlement. The Commission regarded a situation of a dispute concerning crimes against humanity, however, as meriting an ability to resort to the Court without prior efforts to arbitrate, an approach taken as well in the Convention against Genocide. ${ }^{45}$ The Commission also considered whether to permit states to opt out of such compulsory dispute settlement and decided, in paragraph 3, to allow them to do so by filing a declaration. ${ }^{46}$ Paragraph 4 , however, notes that a state may withdraw such a declaration at any time.

Two proposals for draft articles advanced by the special rapporteur were referred to the drafting committee, but ultimately were not adopted. A proposed draft article on "relationship to competent international criminal tribunals" 47 would have provided: "In the event of a conflict between the rights or obligations of a State under the present draft articles and its rights or obligations under the constitutive instrument of a competent international criminal tribunal, the latter shall prevail." ${ }^{48}$ Ultimately, this proposal was viewed as unnecessary and undesirable for various reasons: ${ }^{49}$ the Commission had not identified (and indeed had sought to avoid) any actual conflict between the draft articles and obligations owed by states with respect to such tribunals; concerns were voiced about giving absolute priority to obligations that might arise with respect to any future international criminal tribunal, including at the regional level; creation of such a rule might be confusing in relation to the Rome Statute's principle of complementarity, which grants some deference to national proceedings; ${ }^{.0}$ and standard conflict-resolution rules in international law are available in the unlikely event that a conflict arises.

A proposed draft article on "federal State obligations" committee but not adopted. That draft article would have provided: "The provisions of the present draft articles shall apply to all parts of federal States without any limitations or

\footnotetext{
${ }^{44}$ For a listing of treaties providing the Court with jurisdiction in contentious cases, see http://www.icjcij.org/en/treaties. The last treaty to do so was the Enforced Disappearance Convention, art. 42(1).

${ }^{45}$ Convention on the Prevention and Punishment of the Crime of Genocide, Art. IX, Dec. 9, 1948,78 UNTS 277.

${ }^{46}$ Most treaties that address crimes under national law and that provide for inter-state dispute settlement allow a state party to opt out of compulsory dispute settlement. See, e.g., Convention against Torture, art. 30, para. 2; United Nations Convention against Transnational Organized Crime, art. 35, para. 3; International Convention for the Protection of All Persons from Enforced Disappearance, art. 42, para. 2; United Nations Convention against Corruption, art. 66, para. 3. When this occurs, most states do not opt out. For example, at present there are 181 states parties to the Convention against Corruption; of those, only 42 states parties have filed a reservation declaring that they do not consider themselves bound by paragraph 2 of article 66 .

47 The proposal is explained in the Third Report, supra note 6, at 92-96.

48 Id. at 96.

${ }^{49}$ International Law Commission, Statement of the Chairman of the Drafting Committee, Mr. Aniruddha Rajput, "Crimes against humanity" (June 1, 2017), available at http://legal.un.org/docs/?path=../ilc/documentation/english/statements/2017_dc_chairman_statement_cah.pdf\&lang= E.

${ }^{50}$ See Rome Statute, supra note 8, at art. 17.

51 The proposal is explained at Third Report, supra note 6, at 97-99.
} 
exceptions." 52 While there was no objection to the substance of this provision, it was believed that the issue was already addressed in background rules of treaty law, ${ }^{53}$ and might prove superfluous if states ultimately decide to prohibit reservations to a new convention. ${ }^{54}$

In his third report, the special rapporteur analyzed but did not advance proposals for various issues, an approach that proved agreeable to the Commission. First, the third report surveyed monitoring mechanisms, such as those within the UN system, that already exist relating to crimes against humanity and that could operate in parallel to a convention on crimes against humanity ${ }^{55}$ Further, based largely on a memorandum completed in 2016 by the UN secretariat, ${ }^{56}$ the third report discussed various monitoring mechanisms for other international crimes (for example, torture) that might serve as models for creation of a new monitoring mechanism in a convention on crimes against humanity. ${ }^{57}$ Ultimately, however, the special rapporteur made no specific proposal for a new mechanism, explaining that selection of one "turns less on legal reasoning and more on policy factors, the availability of resources and the relationship of any new mechanism with those that already exist." 58 Among other things, he noted that "such a monitoring mechanism might be developed in tandem with a monitoring mechanism for the Convention on the Prevention and Punishment of the Crime of Genocide, for which there have been periodic calls." 59

Second, while some members of the Commission had expressed an interest in developing a draft article or provision on "concealment of crimes against humanity," the special rapporteur concluded that existing practice did not support such inclusion, since "[m]ost treaties addressing crimes do not seek to single out, as a separate offence, 'concealment' of the crime, leaving that instead to the operation of national laws as they currently exist." 60

Third, citing to existing treaty practice, the special rapporteur did not propose a draft article or provision addressing the immunity of state officials or officials of international organizations. Instead, he urged that the matter be left to treaties on immunities for particular classes of officials and to customary international law. ${ }^{61}$ While the Commission agreed with this approach, the Commission decided to include a provision on a separate matter - the inability of a state official to raise his or her official position as a substantive defense. ${ }^{62}$ Consequently, a new paragraph 5 was added to draft article 6 (on "Criminalization under national law") stating that:

\footnotetext{
52 Id. at 99.

53 Article 29 of the Vienna Convention on the Law of Treaties, May 23, 1969, 1155 UNTS 331, 8 ILM 679 (1969) [hereinafter VCLT] provides: "Unless a different intention appears from the treaty or is otherwise established, a treaty is binding upon each party in respect of its entire territory."

${ }^{54}$ Crimes against humanity, Statement of the Chairman of the Drafting Committee, supra note 49.

55 Third report, supra note 6 , at 100-04.

${ }^{56}$ Memorandum prepared by the secretariat on information on existing treaty-based monitoring mechanisms which may be of relevance to the Commission's future work on the topic "Crimes against humanity," UN Doc. A/CN.4/698 (2016).

57 Third Report, supra note 6, at 105-13.

${ }^{58} \mathrm{Id}$. at 113.

${ }^{59} \mathrm{Id}$.

${ }^{60} \mathrm{Id}$. at $127-28$.

${ }^{61} \mathrm{Id}$. at 131 .

62 This inability to raise one's official position to claim a lack of responsibility is similar to the inability of an alleged offender to raise a "superior order" defense to avoid responsibility. See Draft article 6, para. 4.
} 
"Each State shall take the necessary measures to ensure that, under its criminal law, the fact that an offence referred to in this draft article was committed by a person holding an official position is not a ground for excluding criminal responsibility." 63 Thus, the mere fact that the official in question is, for example, a head of state, does not serve as a substantive defense to any criminal responsibility. By contrast, the commentary to this paragraph explains that "paragraph 5 has no effect on any procedural immunity that a foreign State official may enjoy before a national criminal jurisdiction, which continues to be governed by conventional and customary international law." 64

Fourth, the special rapporteur also analyzed whether the draft articles should explicitly address the issue of amnesty and concluded that they should not, given the mixed nature of state practice relating to amnesties. This conclusion was agreeable to the Commission, but the commentary to draft article 10 (on "Aut dedere aut judicaire") discusses recent practice with respect to amnesties, ${ }^{65}$ and notes

that an amnesty adopted by one State would not bar prosecution by another State with concurrent jurisdiction over the offence. Within the State that has adopted the amnesty, its permissibility would need to be evaluated, inter alia, in the light of that State's obligations under the present draft articles to criminalize crimes against humanity, to comply with its aut dedere aut judicare obligation, and to fulfil its obligations in relation to victims and others. ${ }^{66}$

Fifth, the special rapporteur noted that "final clauses" would need to be developed if the Commission's draft articles were transformed into a convention. The Commission historically has not drafted such clauses for its projects but has left this to the negotiating states (typically with assistance from the UN secretariat's treaty division), who are best equipped to decide issues such as how many ratifications or accessions are needed prior to entry into force of the convention. ${ }^{67}$ Given the interest within the Commission on the issue of reservations and the possible future interest of states, the special rapporteur nevertheless analyzed different possibilities for addressing reservations as a part of the final clauses, such as prohibiting reservations, permitting reservations, or remaining silent on the matter. ${ }^{68}$

The Commission's work on the provisions discussed above allowed it during the sixthninth session to completed its first reading of the topic, approving altogether the preamble, fifteen draft articles, draft annex, and commentary. ${ }^{69}$ Further, the Commission decided to transmit the draft articles to governments, international organizations and others for comments, with the request that they be submitted by December 2018. It is expected that the second reading on this topic will take place in 2019, after which it can be sent in its final form to the UN General Assembly.

\footnotetext{
${ }^{63} I d$. at para. 5.

642017 Report, supra note 1, at 69, para. (31).

${ }^{65} \mathrm{Id}$. at 86-88, paras. (8) - (10).

${ }^{66} I d$. at para. (11).

67 Third Report, supra note 6, at 139.

${ }^{68}$ Id. at $140-50$.

692017 Report, supra note 1 , at 10 .
} 


\section{OTHER TOPICS ADDRESSED DURING THE SIXTY-NINTH SESSION}

\section{Provisional Application of Treaties}

Since 2015, the drafting committee of the Commission has provisionally adopted several guidelines on this topic based on reports by the special rapporteur, Juan Manuel Gómez-Robledo (Mexico).$^{70}$ At the 69th session, the drafting committee principally focused on provisionally adopting three new draft guidelines, all of which concern the relationship of internal (i.e., national or domestic) law to the provisional application of treaties.

Draft guideline 9, paragraph 1, provides that a "State that has agreed to the provisional application of a treaty or a part of a treaty may not invoke the provisions of its internal law as justification for its failure to perform an obligation arising under such provisional application." ${ }^{.71}$ The second paragraph applies the same rule to international organizations that agree to provisionally apply a treaty, but refers to "the rules of the organization" rather than "internal law." These rules echo, respectively, article 27 of the 1969 Vienna Convention on the Law of Treaties (VCLT) ${ }^{72}$ and the 1986 Vienna Convention on the Law of Treaties Between States and International Organizations or Between International Organizations (VCLTIO). ${ }^{73}$

Draft guideline 10, paragraph 1, provides that a

State may not invoke the fact that its consent to the provisional application of a treaty or a part of a treaty has been expressed in violation of a provision of its internal law regarding competence to agree to the provisional application of treaties as invalidating its consent unless that violation was manifest and concerned a rule of its internal law of fundamental importance. ${ }^{74}$

Here, too, the second paragraph applies the same rule to international organizations, again referring to "the rules of the organization" rather than "internal law." These rules echo, respectively, article 46 of the VCLT and the VCLTIO.

Finally, draft guideline 11 provides that the guidelines are "without prejudice to the right of a State or an international organization to agree in the treaty itself or otherwise to the provisional application of the treaty or a part of the treaty with limitations deriving from the

\footnotetext{
${ }^{70}$ For discussion of prior work on these draft guidelines, see Sean D. Murphy, The Expulsion of Aliens and Other Topics: The Sixty-Fourth Session of the International Law Commission, 107 AJIL 164, 171-73 (2013) [hereinafter Murphy, Sixty-Fourth Session]; Sean D. Murphy, Immunity Ratione Personae of Foreign Government Officials and Other Topics: The Sixty-Fifth Session of the International Law Commission, 108 AJIL 41, 53-54 (2014) [hereinafter Murphy, Sixty-Fifth Session]; Sean D. Murphy, The Expulsion of Aliens (Revisited) and Other Topics: The SixtySixth Session of the International Law Commission, 109 AJIL 125, 143-44 (2015) [hereinafter Murphy, Sixty-Sixth Session]; Murphy, Sixty-Seventh Session, supra note 2, at 822-32 (guidelines 1-3); Murphy, Sixty-Eighth Session, supra note 2, at 742-45 (guidelines 4, 6-9; guidelines 6-9 were renumbered in 2017 to be guidelines 5-8).

712017 Annual Report, at 130.

${ }^{72}$ VCLT, supra note 53.

${ }^{73}$ Vienna Convention on the Law of Treaties Between States and International Organizations or Between International Organizations, Mar. 21, 1986, 25 ILM 543 (1986) [hereinafter VCLTIO] (not yet in force).

${ }^{74} 2017$ Annual Report, at 130.
} 
internal law of the State or from the rules of the organization." 75 This guideline essentially acknowledges that, notwithstanding draft guidelines 9 and 10 (as well as the other draft guidelines), states are always free to include in their treaty clauses relating to provisional application limitations deriving from their internal law. ${ }^{76}$

The special rapporteur also requested during the session that a working group be convened to assist in the drafting of commentary. ${ }^{77}$ This was done and, after completion of the commentaries, the Commission adopted draft guidelines 1 through 11 with commentary. ${ }^{78}$ Two salient features of the draft guidelines bear mention.

First, as indicated above, the Commission has infused into these draft guidelines rules relating equally to states and to international organizations. This approach of collapsing together rules relating to two different actors is, for the most part, inconsistent with the prior ${ }^{79}$ and current $^{80}$ work of the Commission, especially in the area of the law of treaties, ${ }^{81}$ where rules relating to the two actors have been kept separate. While doing so provides for some efficiencies, the lower degrees of acceptance associated with the Commission's projects codifying rules relating to international organizations may cast doubt upon the degree to which the draft guidelines on provisional application of treaties reflect settled law.

Second, an issue running through the draft guidelines is the extent to which the law of treaties as a whole applies to the provisional application of treaties. The guidelines by their terms apply only some aspects of the law of treaties (such as Articles 27 and 46 of the VCLT and the

\footnotetext{
${ }^{75} I d$.

${ }^{76}$ See, e.g., Energy Charter Treaty, Art. 45(1), Dec. 17, 1994, 2080 UNTS 95, 34 ILM 360 (1995) (providing that each "signatory agrees to apply this Treaty provisionally pending its entry into force for such signatory in accordance with Article 44, to the extent that such provisional application is not inconsistent with its constitution, laws or regulations").

772017 Annual Report, at 128.

${ }^{78} \mathrm{Id}$.

${ }^{79}$ For example, compare Draft Articles on Responsibility of States for Internationally Wrongful Acts, in Report of the International Law Commission on the Work of Its Fifty-Third Session, UN GAOR, 56th Sess., Supp. No. 10, at 43, UN Doc. A/56/10 (2001), with Draft Articles on the Responsibility of International Organizations, in Report of the International Law Commission on the Work of Its Sixty-Third Session, UN GAOR, 66th Sess., Supp. No. 10, at 54, UN Doc. A/66/10 (2011).

${ }^{80}$ For example, the Commission's current project on subsequent agreement and subsequent practice in relation to the interpretation of treaties is based on the 1969 VCLT, not on both the 1969 VCLT and 1986 VCLTIO. See 2016 Report, supra note 5, at 124. Likewise, in the Commission's current project on jus cogens (discussed below), the focus to date is on acceptance and recognition of a norm as jus cogens "by a very large majority of States" and while "the positions of other actors may be relevant in providing context and for assessing acceptance and recognition by the international community of States as a whole, these positions cannot, in and of themselves, form a part of such acceptance and recognition." See International Law Commission, Statement of the Chairman of the Drafting Committee, Mr. Aniruddha Rajput, "Peremptory Norms of General International Law (Jus Cogens)," annex (July 26, 2017), available at file://C:/Users/Owner/Documents/ILC/CANZ\%20Briefing\%20(Aug\%202017)/Jus\%20Cogens\%20Drafting\%20Co $\mathrm{mm} \% 20$ Report.pdf. On the other hand, the Commission's current project on identification of customary international law assimilates states and international organizations to a degree in draft conclusion 4 . It provides that the "practice" at issue throughout the draft conclusions is "primarily" the practice of states but also consists "[i]n certain cases" of international organizations. See 2016 Report, supra note 5, at 76.

${ }^{81}$ The principal examples being the Commission's draft articles leading to the 1969 VCLT (focused on states) and the 1986 VCLTIO (focused on international organizations).
} 
VCLTIO) to provisional application, which implies that the law of treaties as a whole does not so apply. This approach is correct, given that large portions of the law of treaties, such as rules on reservations, entry into force, termination, suspension, and dispute settlement do not appear pertinent to provisional application of a treaty. At the same time, draft guideline 6 (on "Legal effects of provisional application") provides that the provisional application of a treaty "produces the same legal effects as if the treaty were in force...." 82 This is a very broad proposition, one that seems doubtful if it means that the legal situation for provisional application of a treaty is the same as if the treaty were in force. What is likely meant by the Commission is that when a state agrees to provisionally apply a treaty, it assumes a legally binding obligation to apply the treaty or the part of the treaty in question. If so, then draft guideline 6 might be usefully revised along those lines at first reading.

The special rapporteur has indicated that he will submit a fifth report in 2018 which, among other things, may indicate "model clauses" for use when states or international organizations wish to provisionally apply a treaty. ${ }^{83}$ Further, the special rapporteur would like to complete the first reading on this topic in 2018.

\section{Protection of the Atmosphere}

In prior sessions, the Commission adopted preambular paragraphs and draft guidelines 1 to 8 for its topic on the protection of the atmosphere. ${ }^{84}$ During the 69 th session, the Commission considered the fourth report by the special rapporteur, Shinya Murase (Japan), which proposed four more draft guidelines. ${ }^{85}$ Based on that report, the Commission adopted three further preambular paragraphs, as well as one new draft guideline, with commentary. ${ }^{86}$

The new draft preambular paragraphs are as follows: "Noting the close interaction between the atmosphere and the oceans"; 87 "Aware also, in particular, of the special situation of low-lying coastal areas and small island developing States due to sea-level rise"; 88 and "Noting that the interests of future generations of humankind in the long-term conservation of the quality of the atmosphere should be fully taken into account." 89

New draft guideline 9 on "Interrelationship among relevant rules" seeks to provide guidance as to the "harmonization and systemic integration" of rules ${ }^{90}$ that may relate to

\footnotetext{
822017 Report, supra note 1, at 129.

${ }^{83}$ International Law Commission, Fourth Report on the Provisional Application of Treaties, at 38, para.182, UN Doc. A/CN.4/699 (June 23, 2016) (prepared by Special Rapporteur Juan Manuel Gómez-Robledo).

${ }^{84}$ For discussion of prior work on this topic, see Murphy, Sixty-Fifth Session, supra note 70, at 56-57; Murphy, Sixty-Sixth Session, supra note 70, at 139; Murphy, Sixty-Seventh Session, supra note 2, at 832-35; Murphy, SixtyEighth Session, supra note 2, at 729-30.

${ }^{85}$ See International Law Commission, Fourth Report on the Protection of the Atmosphere, UN Doc. A/CN.4/705 (Jan. 31, 2017) (prepared by Special Rapporteur Shinya Murase).

${ }^{86} 2017$ Report, supra note 1, at 151, para. 67.

${ }^{87} \mathrm{Id}$. at 151.

${ }^{88} \mathrm{Id}$. at 152.

${ }^{89} \mathrm{Id}$. at 153.

${ }^{90}$ For recent scholarship on this issue, see Campbell McLachlan, The Principle of Systemic Integration and Article 31(3)(c) of the Vienna Convention, 54 INT'L \& COMP. L.Q. 279 (2005); Adamantia Rachovitsa, The Principle of Systemic Integration in Human Rights Law-A Critical Appraisal, 66 INT’L \& COMP. L.Q. 557 (2017).
} 
protection of the atmosphere. Drawing in part upon the work of the Commission's 2006 study group report on the Fragmentation of international law: Difficulties arising from the diversification and expansion of international law ${ }^{91}$ draft guideline 9 provides:

1. The rules of international law relating to the protection of the atmosphere and other relevant rules of international law, including inter alia the rules of international trade and investment law, of the law of the sea and of international human rights law, should, to the extent possible, be identified, interpreted and applied in order to give rise to a single set of compatible obligations, in line with the principles of harmonization and systemic integration, and with a view to avoiding conflicts. This should be done in accordance with the relevant rules set forth in the Vienna Convention on the Law of Treaties of 1969, including articles 30 and 31, paragraph 3 (c), and the principles and rules of customary international law.

2. States should, to the extent possible, when developing new rules of international law relating to the protection of the atmosphere and other relevant rules of international law, endeavour to do so in a harmonious manner.

3. When applying paragraphs 1 and 2, special consideration should be given to persons and groups particularly vulnerable to atmospheric pollution and atmospheric degradation. Such groups may include, inter alia, indigenous peoples, people of the least developed countries and people of low-lying coastal areas and small island developing States affected by sea level rise. ${ }^{92}$

The special rapporteur intends to submit a fifth report for the 70th session addressing implementation in national law, compliance in international law, and dispute settlement. Moreover, he hopes to complete the first reading of this topic in 2018.

\section{Immunity of State Officials from Foreign Criminal Jurisdiction}

Towards the end of the sixty-eighth session in 2016, the Commission received the fifth report on "immunity of State officials from foreign criminal jurisdiction" by its second special

\footnotetext{
${ }^{91}$ International Law Commission, Fragmentation of International Law: Difficulties Arising from the Diversification and Expansion of International Law: Report of the Study Group of the International Law Commission, 58th Sess., U.N. Doc. A/CN.4/L.682 (Apr. 13, 2006), as corrected U.N. Doc. A/CN.4/L.682/Corr.1 (Aug. 11, 2006). There were forty-two conclusions associated with the report. See Rep. of the International Law Commission, 58th Sess., May 1-June 9, July 3-Aug. 11, 2006, U.N. Doc. A/61/10; GAOR, 61st Sess., Supp. No. 10, at 407-23 (2006) (presenting the Study Group's Conclusions). Neither the Report nor the Conclusions were adopted by the Commission. The Commission, however, "decided to take note" of the Conclusions, "commended them to the attention of the General Assembly," and requested that the Report be made available on the Commission's website and published in its Yearbook. Id. at 402. Thereafter, the General Assembly also took note of the Conclusions "together with" the Report on which they were based. G.A. Res. 61/34, - 4, U.N. Doc. A/RES/61/34, at 2 (Dec. 18, 2006).

922017 Report, supra note 1, at 155.
} 
rapporteur for this topic, Concepción Escobar Hernández (Spain). ${ }^{93}$ which proposed a single draft article 7 on "crimes in respect of which immunity does not apply," reading as follows:

1. Immunity shall not apply in relation to the following crimes:

(i) Genocide, crimes against humanity, war crimes, torture and enforced disappearances;

(ii) Corruption-related crimes;

(iii) Crimes that cause harm to persons, including death and serious injury, or to property, when such crimes are committed in the territory of the forum State and the State official is present in said territory at the time that such crimes are committed.

2. Paragraph 1 shall not apply to persons who enjoy immunity ratione personae during their term of office.

3. Paragraphs 1 and 2 are without prejudice to:

(i) Any provision of a treaty that is binding on the forum State and the State of the official, under which immunity would not be applicable;

(ii) The obligation to cooperate with an international tribunal which, in each case, requires compliance by the forum State.

The debate on the fifth report, including this proposed draft article, commenced during the sixth-eighth session in 2016, but could not be completed due to a lack of time, and so was continued in the sixty-ninth session. That debate, as well as the ensuing discussions within the drafting committee and during the adoption of the commentary to draft article 7 , proved to be one of the most contentious within the Commission in years.

Divisions within the Commission on this issue have been apparent since $2008^{94}$ and especially since 2011, when the Commission debated the second report of the prior special rapporteur, Roman Kolodkin, who found that there were no exceptions either to immunity

\footnotetext{
${ }^{93}$ International Law Commission, Fifth Report on Immunity of State Officials from Foreign Criminal Jurisdiction, UN Doc. A/CN.4/701 (June 14, 2016) (prepared by Special Rapporteur Concepción Escobar Hernández) [hereinafter Fifth Report on Immunity of State Officials]. For discussion of prior work on this topic, see Murphy, Sixty-Fourth Session, supra note 70, at 169-71; Murphy, Sixty-Fifth Session, supra note 70, at 41-48; Murphy, Sixty-Sixth Session, supra note 70, at 139-40; Murphy, Sixty-Seventh Session, supra note 2, at 842.

${ }^{94}$ Report of the International Law Commission on the Work of Its Sixty-Third Session, UN GAOR, 63rd Sess., Supp. No. 10, at 335-38, paras. 294-99, UN Doc. A/63/10 (2008).
} 
ratione persona $e^{95}$ or to immunity ratione materiae of state officials. ${ }^{96}$ Even so, these divisions remained dormant during the initial work of the current special rapporteur, who avoided addressing "exceptions and limitations" until her fifth report. During the first part of the debate on the report in 2016, views both for and against the draft article were expressed. ${ }^{97}$ Likewise, during the second part of the debate in May 2017, views both for and against the draft article were expressed. ${ }^{98}$ At the end of the debate, the special rapporteur recommended that the draft article be referred to the drafting committee. Discussion commenced on whether to do so, but was cut short by a point of order by a member of the Commission, who moved to end the debate without hearing from further speakers who wished to address the matter. ${ }^{99}$ That motion carried by a majority vote ${ }^{100}$ after which draft article 7 was referred to the drafting committee.

The drafting committee met seven afternoons in July 2017 to rework draft article 7 from the proposal contained in the special rapporteur's fifth report. The chairman later reported to the Commission that

the Drafting Committee proceeded in its work on the general understanding that the outcome of its work was without prejudice to, or taking a position on, the question whether the text of draft article 7, or any part thereof, codified existing law - reflecting lex lata - or whether the result constituted an exercise in progressive development, reflecting lex ferenda. Indeed, some members of the Drafting Committee underlined that their participation was without prejudice to the fundamental problems that they had with the text as proposed, as well as the text as finally adopted. The view was expressed that the Drafting Committee was essentially embarking on a policy-making exercise as opposed to seeking the codification or progressive development of the law. Some of those members would have preferred that the draft article was retained in the Drafting Committee until next year, to be further considered with any other proposals on the procedural aspects to be made by the Special Rapporteur. However, other members considered that this was an appropriate time for the Drafting Committee to proceed with the issue. ${ }^{101}$

\footnotetext{
${ }^{95}$ No exceptions or limitations to immunity ratione personae have been proposed or adopted within the Commission. The Commission, however, has previously decided on a provision that would restrict such immunity to heads of state, heads of government, and foreign ministers, and only during their time in office. See 2017 Report, supra note 1 , at 175 (draft article 4).

${ }^{96}$ See Second Report of Roman Kolodkin, UN Doc. A/CN.4/631, at 56, para. 90 (2010) ("In the opinion of the Special Rapporteur, the arguments set out above demonstrate that the various rationales for exceptions to the immunity of officials from foreign criminal jurisdiction prove upon close scrutiny to be insufficiently convincing."). For the summary records of the interventions in the Commission's 2011 debate, see A/CN.4/SR.3086-3088 and 3111-3115. For a general summary of the debate, see Chapter VII of the 2011 Annual Report.

${ }^{97}$ For summaries of the interventions in the first part of the debate, see UN Docs. A/CN.4/SR.3328-3331 (2016). For a general summary of this part of the debate, see Chapter XI of 2016 Report, supra note 5, at 341-63.

${ }^{98}$ For summaries of the interventions in the second part of the debate, see UN Docs. A/CN.4/SR.3360-3365 (2017). For a general summary of this part of the debate, see Chapter VII of the 2017 annual report, supra note 1, at 163-91. ${ }^{99}$ See UN Doc. A/CN.4/SR.3365 at 18. The same member earlier in the morning had urged that members wait until after the summing up by the special rapporteur to discuss issues concerning referral of draft article 7 to the drafting committee. Id. at 7-8.

${ }^{100}$ See id. at 18.

${ }^{101}$ International Law Commission, Statement of the Chairperson of the Drafting Committee, Mr. Aniruddha Rajput, "Immunity of State Officials from Foreign Criminal Jurisdiction," 3 (July 20, 2017), available at
} 
The drafting committee ultimately decided to send the revised draft article 7, along with a draft annex, to the plenary, even though some members "were firmly of the view that it did not reflect existing law ...; they considered that the provision should only be forwarded together with procedural safeguards, given the serious risk of abuse; and they did not support the proposal even as one for new law."102

Draft article 7 and the draft annex as they emerged from the drafting committee read as follows:

Article 7

Crimes under international law in respect of which immunity ratione materiae shall not apply

1. Immunity ratione materiae from the exercise of foreign criminal jurisdiction shall not apply in respect of the following crimes under international law:

(a) crime of genocide;

(b) crimes against humanity;

(c) war crimes;

(d) crime of apartheid;

(e) torture;

(f) enforced disappearance.

2. For the purposes of the present draft article, the crimes under international law mentioned above are to be understood according to their definition in the treaties enumerated in the annex to the present draft articles.

Annex

List of treaties referred to in draft article 7, paragraph 2

Crime of genocide

- Rome Statute of the International Criminal Court, 17 July 1998, article 6;

- Convention on the Prevention and Punishment of the Crime of Genocide, 9

December 1948, article II.

Crimes against humanity

- Rome Statute of the International Criminal Court, 17 July 1998, article 7.

http://legal.un.org/docs/?path=../ilc/documentation/english/statements/2017_dc_chairman_statement_iso.pdf\&lang= $\mathrm{E}$

102 Id. at 13 . 
War crimes

- Rome Statute of the International Criminal Court, 17 July 1998, article 8, paragraph 2.

Crime of apartheid

- International Convention on the Suppression and Punishment of the Crime of Apartheid, 30 November 1973, article II.

Torture

- Convention against Torture and Other Cruel, Inhuman or Degrading Treatment or Punishment, 10 December 1984: article 1, paragraph 1.

Enforced disappearance

- International Convention for the Protection of All Persons from Enforced Disappearance, 20 December 2006, article 2.

Upon receipt in the plenary of this draft article and annex, consensus could not be reached within the Commission on its provisional adoption. On July 20, after several members addressed the Commission as to their concerns, the Commission provisionally adopted the draft article and annex by a recorded vote of $21-8-1$ (with 4 members absent). ${ }^{103}$ Thereafter, the special rapporteur proposed commentary for the draft article and annex, ${ }^{104}$ which was then revised and adopted by the Commission at meetings on August 3-4. ${ }^{105}$ Given the divergences within the Commission on draft article 7, as evidenced by the plenary debate in 2016 and 2017, the recorded vote, and the commentary, the adoption of draft article 7 cannot be seen as expressing a view by the Commission that such exceptions to the immunity ratione materiae of state officials from foreign criminal jurisdiction is lex lata.

At its heart, there are probably two aspects that divide the Commission on this issue. First, many members approve of draft article 7 and its annex despite the lack of widespread and representative state practice in support of them, which troubles other members. Rather than based on state practice, the view of at least some members in the majority is anchored in a belief that there is "a discernible trend towards limiting the applicability of immunity ... in respect of certain types of behavior that constitute crimes under international law,"106 and a belief that exceptions to immunity are necessary to uphold "an international legal order whose unity and systemic nature cannot be ignored." 107 The ultimate objective of these members appears to be to have the Commission shape decision-making in national courts, rather than to codify state practice, including that of those courts, as it presently exists. Second, these members do not wish to characterize draft article 7 and its annex as "progressive development" of the law, let alone as a proposal for new law (to be embodied in a treaty that states could choose whether to ratify). Were such members (including the special rapporteur) willing to do so, it might provide a way

${ }^{103}$ For summaries of the interventions on whether to adopt draft article 7 and the annex, see UN Docs.A/CN.4/SR.3378 (2017). For the record of the vote, see 2017 Annual Report, Chapter VII, at 164-65.

${ }^{104}$ UN Doc. A/CN4/L.903/Add.2.

105 UN Docs. A/CN.4/SR.3387-3389 (2017).

1062017 Report, supra note 1, at 178-79, para. (5).

${ }^{107}$ Id. at 181, para. (6). 
for other members to join a consensus, but it might also undercut the underlying objective of influencing decision-making in national courts.

This is unfortunate, given that a review of interventions in the plenary by members suggest that many who supported draft article 7 actually do not consider that the special rapporteur had demonstrated it to be lex lata. ${ }^{108}$ Indeed, the special rapporteur herself ultimately admitted that there was a general understanding that what had been identified in support of draft article 7 was only a "trend" and not "a customary norm."109

Some aspects of the text of draft article 7 and its commentary also tend to confirm its questionable status as customary international law. The language "shall not apply" in paragraph 1 , for example, is suggestive of treaty language, perhaps indicating that the draft articles must be transformed into a convention to become law. Further, the first sentence of the first paragraph of the commentary was changed from originally reading that draft article 7 "refers to crimes under international law in respect of which immunity from foreign criminal jurisdiction ratione materiae does not apply" 110 to instead read that it "lists crimes under international law in respect of which immunity from foreign criminal jurisdiction ratione materiae shall not apply under the present draft articles." "111 Again, such language may suggest that the exceptions only arise with respect to the present draft articles, which must be transformed into a convention for such exceptions to have legal consequence. When drafting the first paragraph of the commentary, the following sentence reflecting the statement of the chairman of the drafting committee cited above was proposed for inclusion:

The Commission proceeded in its work on the general understanding that the outcome of its work was without prejudice to, or taking a position on, the question whether the text of

\footnotetext{
${ }^{108}$ A/CN.4/SR.3360 at 8 (statement of Mr. Park) ("Given the uncertainty of that situation, it would be better to consider such a limitation or exception as lex ferenda."); A/CN.4/SR. 3361 at 6 (statement of Mr. Tladi) (noting that while the Commission did not need to define whether each article was lex lata or lex ferenda, "ways could be found to reflect the fact that relevant law was in a state of flux"); id. at 9 (statement of Ms. Galvão Teles) (stating that "current practice in relations to immunity was not clear enough to enable approaches applicable to all aspects of the limitations and exceptions to immunity, particularly immunity ratione materiae"); A/CN.4/SR.3362 at 3 (statement of Mr. Vázquez Bermúdez) (finding that there was "at least a clear trend towards the emergence of a customary rule"); $i d$. at 9 (statement of Mr. Sturma) ("Although State practice afforded a number of examples supporting the idea that there were exceptions to the immunity of State officials, such practice was far from uniform and also offered good arguments to the contrary."); $i d$. at 10 (statement of Ms. Lehto) (finding that it was "difficult to identify the existence of a clear and undisputed customary law rule" granting immunity of State officials from foreign criminal jurisdiction); id. at 12 (statement of Mr. Jalloh) (stating that customary international law does not provide exceptions to immunity for war crimes, crimes against humanity, and genocide); A/CN.4/SR.3364 at 3 (statement of Ms. Oral) ("It was indeed questionable whether there was adequate support for concluding that customary law permitted any exceptions to immunity ratione materiae from foreign criminal jurisdiction."); id. at 6 (statement of Mr. Cissé) (noting "there could be no doubt that a customary rule did not exist"); Statement of Mr. August Reinisch, Member of the International Law Commission 1 (May 24, 2017) (on file with author) ("I also have some doubts about the qualification of certain developments as already reflective of established custom.").

${ }^{109}$ See A/CN.4/SR.3388 at 4; see also Recording of the International Law Commission's 3388th meeting, Aug. 3, 2017, at time 24:55 ("En lo que sí hubo un planteamiento general, o una posición general, es en señalar que lo que sí se puede identificar es una tendencia, no una norma consuetudinaria, y eso está clarísimamente expresado en el comentario.").

${ }^{110}$ A/CN.4/L.903/Add.2, at 2, para. (1) (July 19, 2017).

1112017 Report, supra note 1, at 176, para. (1) (emphasis added).
} 
draft article 7, or any part thereof, codified existing law - reflecting lex lata - or whether the result constituted an exercise in progressive development, reflecting lex ferenda. ${ }^{12}$

While that sentence ultimately was not included, the discussion within the plenary indicates that members of the Commission opposed adding the sentence not because they disagreed with its substance, but because the issue had already been reflected in the drafting committee chairman's statement and did not need to be replicated in the first paragraph of the commentary, or because it was improper to address the matter one way or the other in commentary. ${ }^{113}$ Finally, the commentary also sets out extensively the views of the minority, pointing out what it perceives as deficiencies in the majority's reasoning; in this regard, one might compare the sources cited by the majority, ${ }^{114}$ with the critique of those sources by the minority. ${ }^{115}$

Not included in draft article 7 as provisionally adopted by the Commission are two exceptions to immunity that had been proposed by the special rapporteur in her fifth report. An exception to immunity for crimes of corruption is not included, ${ }^{116}$ because the Commission decided that "they do not constitute 'acts performed in an official capacity,' but are acts carried out by a State official solely for his or her own benefit." 117 The Commission asserts that "corruption" is to be understood as "grand corruption," "118 a term left unspecified in the commentary, even though the special rapporteur previously had indicated that it would be explained. ${ }^{119}$

112 See A/CN.4/SR.3387 at 10.

${ }^{113}$ See A/CN.4/SR.3387 at 10-13; see also Recording of the International Law Commission's 3387th meeting, Aug. 3, 2017, at time 103:12 (Dire Tladi (South Africa): while opposing inclusion of the sentence, "this is without prejudice to my own views about the extent to which this reflects or does not reflect law"); at time 112:30 (Marcelo Vázquez-Bermúdez (Ecuador): "Tenemos entendido que la Comisión está trabajando dentro de su mandato general de desarrollo progresivo y codificación."; translation: "We understand that the Commission is working within its general mandate of progressive development and codification."); at time 127:55 (Georg Nolte (Germany): "I have not heard an argument that the sentence was wrong in substance... There was not a majority of members who said that draft article 7 is customary international law. There is a number of members who voted in favor of draft article 7 but who also said it was an exercise in progressive development."); at time 130:32 (Pavel Šturma (Czech Republic): "I don't have substantive problems with the proposal. I think the Commission is divided."); at time 136:45 (Kigab Park (South Korea): "Concerning the insertion of a new sentence. I can accept as it is because there is no substantive difficulty ...."; at time 137:49 (Aniruddha Rajput (India): "The sense that I got of the debate was that we are not disagreeing as to which domain we are in. We are progressively developing. There is no problem with the substance of the second sentence. What I understood was that there is a problem with whether to have it or not to have it."); at time 152:20 (Sean Murphy (United States): "What I've heard from those that are not happy with the sentence I was proposing was not so much on the substance of it but more on the placement or the propriety, given our other work ... I'll withdraw the sentence, although I think that the debate suggested that this is in fact the view of the Commission.").

1142017 Report, supra note 1, at 178-81, paras. (5) - (7) (including footnotes 762-64).

${ }^{115} \mathrm{Id}$. at 181-83, para. (8) (including footnotes 765-68); see also id., at 185, para. (17) ("Some members noted, however, that the inclusion of [the crime of genocide, crimes against humanity, and war crimes] in draft article 7 found little if any support in practice, in national and international jurisprudence or in national legislation."); id. at 187, para. (19) ("Some members noted, however, that the inclusion of [the crime of apartheid, torture and enforced disappearance] in draft article 7 found little if any support in practice, in national and international jurisprudence or in national legislation.”).

${ }^{116}$ Fifth Report, supra note 93, at 90-92, 95 (proposing an exception for "corruption-related crimes").

1172017 Report, supra note 1, at 188, para. (23).

${ }^{118} \mathrm{Id}$. at 188 , para. (22).

${ }^{119} \mathrm{Id}$. at 124, para. 138 (special rapporteur indicating "that the provision should principally apply to matters of 'grand corruption', a term that was to be further specified in the commentaries"). 
Likewise, no exception for "territorial crimes" is included in draft article 7, by which is meant (according to the commentary) crimes committed "by a foreign official in the territory of the forum State without that State's consent to both the official's presence in its territory and the activities carried out by the official that gave rise to the commission of the crime." 120 Interestingly, this is the one exception that the prior special rapporteur, Roman Kolodkin, believed might exist under customary international law, ${ }^{121}$ as did the current special rapporteur. ${ }^{122}$ The explanation for not including this exception in draft article 7 is unclear; as was the case for corruption, the Commission appears to believe that such "territorial crimes" simply "do not give rise to immunity from jurisdiction ratione materiae" ${ }^{123}$ but, unlike corruption, this outcome cannot be explained on the basis that the acts are not official in nature. Indeed, if the "territorial crimes" at issue are acts by a foreign government official who, for example, sneaks into a country so as to commit an assassination, espionage, sabotage or kidnapping, ${ }^{124}$ such acts would appear to be "official" in nature (and not for the personal gain of the official).

Certain other crimes discussed within the Commission also were not included in draft article 7, including the crimes of aggression, ${ }^{125}$ slavery, terrorism, human trafficking, child prostitution, child pornography, and piracy. ${ }^{126}$ Various members who had supported draft article 7 nevertheless objected to the lack of the inclusion of one or more of these crimes, again casting doubt on the status of draft article 7 as lex lata. The reasoning for including or excluding crimes on the draft article 7 list was characterized by one member as an exercise in "arbitrary progressive development." 127

The special rapporteur has indicated that her next report will address procedural provisions and safeguards, after which this topic will be ready for completion on first reading. The exact types of safeguards that might be included are not yet known, but might include the following. First, a forum state might only deny immunity ratione materiae on the basis of an exception contained in draft article 7 when (a) the current or former state official is present in the forum state; (b) the alleged crime was committed in territory under the forum state's jurisdiction; (c) the evidence that the official committed the alleged offense is fully conclusive; and (d) the decision to pursue a criminal proceeding against the official is taken at the highest level that is

\footnotetext{
${ }^{120} I d$. at 188 , para. (24).

${ }^{121}$ Kolodkin Second Report, supra note 96, at 59-60 ("A situation where criminal jurisdiction is exercised by a State in whose territory an alleged crime has taken place, and this State has not given its consent to the performance in its territory of the activity which led to the crime and to the presence in its territory of the foreign official who committed this alleged crime, stands alone in this regard as a special case. It would appear that in such a situation there are sufficient grounds to talk of an absence of immunity.").

${ }^{122}$ Fifth Report, supra note 93, at 88-89, 95 (proposing an exception for crimes "that cause harm to persons, including death and serious injury, or to property, when such crimes are committed in the territory of the forum State and the State official is present in said territory at the time that such crimes are committed").

1232017 Report, supra note 1, at 188, para (24).

${ }^{124}$ Id. The Commission's commentary refers generally to "murder" though what is likely meant is not a common crime of murder but, rather, murder of an important person for political purposes (assassination).

${ }^{125} I d$. at $185-86$, para. (18).

${ }^{126} I d$. at 187 , para. (20).

${ }^{127}$ Recording of the International Law Commission's 3387th meeting, Aug. 3, 2017, at time 123:47 ("If ever this Commission had in front of itself something which was typical progressive development, then it's this article 7 . It is not only progressive development. It is rather arbitrary progressive development. And not even agreed in this Commission.”) (comment of Ernest Petrič (Slovenia)).
} 
appropriate under the forum state's national law. Second, if a decision is taken by the forum state to pursue a criminal proceeding, the forum state might be required to: (a) notify the state of the official that it intends to pursue a criminal proceeding; and (b) if that other state is able and willing to submit the matter to prosecution in its own courts, then the proceeding must be transferred to that other state.

\section{Peremptory Norms of General International Law (Jus Cogens)}

During the sixty-seventh session, the Commission moved the topic of jus cogens onto the current program of work and appointed Dire D. Tladi (South Africa) as special rapporteur. ${ }^{128}$ While some work was completed during the sixty-eighth session based on the special rapporteur's first report, ${ }^{129}$ considerable progress was made in the drafting committee during the sixty-ninth session after the debate on his second report. ${ }^{130}$ In addition, the title of the topic was changed from just "Jus cogens" to "Peremptory norms of general international law (jus

cogens)." ${ }^{\prime 31}$ To date, the drafting committee has provisionally adopted the following seven draft conclusions. ${ }^{132}$

Draft conclusion 1

Scope

The present draft conclusions concern the identification and legal effects of peremptory norms of general international law (jus cogens).

Draft conclusion 2

General nature of peremptory norms of general international law (jus cogens)

Peremptory norms of general international law (jus cogens) reflect and protect fundamental values of the international community, are hierarchically superior to other rules of international law and are universally applicable.

Draft conclusion 3

Definition of a peremptory norm of general international law (jus cogens)

A peremptory norm of general international law (jus cogens) is a norm accepted and recognized by the international community of States as a whole as a norm from which no derogation is permitted and which can be modified only by a subsequent norm of general international law having the same character.

\section{Draft conclusion 4}

\footnotetext{
${ }^{128}$ Report of the International Law Commission on the Work of Its Sixty-Seventh Session, UN GAOR, 70th Sess., Supp. No. 10, at 138, para. 286, UN Doc. A/70/10 (Aug. 14, 2015).

${ }^{129}$ For discussion of prior work on this topic, see Murphy, Sixty-Eighth Session, supra note 2, at 730-31.

${ }^{130}$ See International Law Commission, Second Report on Jus Cogens, UN Doc. A/CN.4/706 (Mar. 16, 2017) (prepared by Special Rapporteur Dire Tladi).

1312017 Report, supra note 1, at 193.

${ }^{132}$ Peremptory Norms of General International Law (Jus Cogens), Statement of the Chairman of the Drafting Committee, supra note 80 , at 2, 10-12.
} 
Criteria for identification of a peremptory norm of general international law (jus cogens)

To identify a peremptory norm of general international law (jus cogens), it is necessary to establish that the norm in question meets the following criteria:

(a) it is a norm of general international law; and

(b) it is accepted and recognised by the international community of States as a whole as a norm from which no derogation is permitted and which can be modified only by a subsequent norm of general international law having the same character.

Draft conclusion 5

Bases for peremptory norms of general international law (jus cogens)

1. Customary international law is the most common basis for peremptory norms of general international law (jus cogens).

2. Treaty provisions and general principles of law may also serve as bases for peremptory norms of general international law (jus cogens).

Draft conclusion 6

Acceptance and recognition

1. The requirement of "acceptance and recognition" as a criterion for identifying a peremptory norm of general international law (jus cogens) is distinct from acceptance and recognition as a norm of general international law.

2. To identify a norm as a peremptory norm of general international law (jus cogens), there must be evidence that such a norm is accepted and recognized as one from which no derogation is permitted and which can only be modified by a subsequent norm of general international law having the same character.

Draft conclusion 7

International community of States as a whole

1. It is the acceptance and recognition by the international community of States as a whole that is relevant for the identification of peremptory norms of general international law (jus cogens).

2. Acceptance and recognition by a very large majority of States is required for the identification of a norm as a peremptory norm of general international law (jus cogens); acceptance and recognition by all States is not required.

3. While the positions of other actors may be relevant in providing context and for assessing acceptance and recognition by the international community of States as 
a whole, these positions cannot, in and of themselves, form a part of such acceptance and recognition.

These draft conclusions have not yet been adopted by the Commission, as the special rapporteur prefers to wait until all the draft conclusions have been completed in the drafting committee before drafting commentary, and the Commission only adopts draft articles or conclusions simultaneously with their commentary. The special rapporteur has indicated that a third report in 2018 might consider the consequences of jus cogens, while a fourth report in 2019 could address miscellaneous issues. ${ }^{133}$

\section{Succession of States in Respect of State Responsibility}

During May of the sixty-ninth session, the Commission moved the topic of succession of states in respect of state responsibility onto the current program of work and appointed Pavel Šturma (Czech Republic) as special rapporteur. ${ }^{134}$ Generally speaking, this topic will analyze the rules on state responsibility applicable to the rights and obligations of a predecessor state, a successor state, and third states, in situations where a succession of states occurs. ${ }^{135}$ In recent years, other bodies have also studied this issue, notably the International Law Association ${ }^{136}$ and the Institut de Droit International. ${ }^{137}$

The special rapporteur produced a first report ${ }^{138}$ in time for debate during the July session, which resulted in the transmittal of four draft articles to the drafting committee. During the session, the drafting committee provisionally adopted draft article 1 on "scope" of the draft articles, which simply provides that the "present draft articles apply to the effects of a succession of States in respect of the responsibility of States for internationally wrongful acts." 139 Further, the drafting committee provisionally adopted portions of draft article 2 on "use of terms," which replicates four definitions contained in prior instruments concerning secession issues 140 (specifically, definitions for "succession of States," "predecessor State," "successor State," and "date of the succession of States"). ${ }^{141}$

\footnotetext{
${ }^{133}$ Second Report on Jus Cogens, supra note 130, at 46, para. 76.

${ }^{134}$ Report of the International Law Commission on the Work of Its Sixty-Seventh Session, UN GAOR, 70th Sess., Supp. No. 10, at 138, para. 286, UN Doc. A/70/10 (2015).

${ }^{135}$ For the syllabus of the topic, see 2016 Report, supra note 80, at 400, Annex B.

${ }^{136}$ International Law Association, Report of the Seventy-Third Conference, Rio de Janeiro, Aug. 17-21 2008, pp. 250 et seq.

${ }^{137}$ Institute of International Law, Fourteenth Commission, State Succession in Matters of State Responsibility, Provisional Report of the Rapporteur, Mr. Marcelo G. Kohen; Institute of International Law, Resolution on Succession of States in Matters of International Responsibility, Aug. 28, 2015.

${ }^{138}$ See International Law Commission, First Report on Succession of States in Respect of State Responsibility, UN Doc. A/CN.4/708 (May 31, 2017) (prepared by Special Rapporteur Pavel Šturma).

${ }^{139}$ International Law Commission, Statement of the Chairman of the Drafting Committee, Mr. Aniruddha Rajput, "Succession of States in Respect of State Responsibility," annex (July 31, 2017), available at http://legal.un.org/docs/?path=../ilc/documentation/english/statements/2017_dc_chairman_statement_ssrsr.pdf\&lang $=\mathrm{E}$.

${ }^{140}$ See Vienna Convention on Succession of States in Respect of Treaties, Aug. 23, 1978, 1946 UNTS 3; Vienna Convention on Succession of States in Respect of State Property, Archives and Debts (Vienna, 8 April 1983), United Nations, Juridical Yearbook 1983 (not yet in force); Articles on Nationality of Natural Persons in Relation to the Succession of States, United Nations General Assembly, Resolution 55/153 of 12 December 2000, Annex. ${ }^{141}$ Succession of States in Respect of State Responsibility, Statement of the Chairman of the Drafting Committee,
} 
One issue that featured during the Commission's debate of the first report was whether one could identify a general rule concerning the transfer of rights and obligations from a predecessor state to a successor state. The first report noted that the general rule articulated in scholarly writings ${ }^{142}$ is that there is no such transfer, at least with respect to obligations. At the same time, the first report appears to suggest that contemporary practice may indicate acceptance of an automatic transfer of rights or obligations from a predecessor state to a successor state. ${ }^{143}$ Yet the first report ultimately took no definitive position as to which view was correct, nor did it advance a draft article that articulates a general rule one way or another.

Not resolving the content of the general rule made it difficult to determine how best to write draft articles 3 and 4 as proposed by the special rapporteur, because those articles are essentially trying to explain when it is that there might be divergences from the general rule. Proposed draft article 3 is focused on the possibility of a bilateral agreement setting forth a special rule that governs in a particular situation, ${ }^{144}$ while draft article 4 is focused on the possibility of a unilateral declaration by a successor state setting forth a special rule that governs in a particular situation. ${ }^{145}$ Knowing the content of the general rule would help in determining how best to characterize these divergences. While these two proposed draft articles were referred to the drafting committee, it was agreed that work on them would be undertaken during the seventieth session, at which time the special rapporteur's second report will be available.

According to the special rapporteur, the second report will address issues concerning transfer of the obligations arising from the internationally wrongful act of the predecessor state, and will distinguish situations where that state has disappeared (such as dissolution) and situations where that state remains (such as secession). A third report in 2019 will focus on the transfer of the rights or claims of an injured predecessor state to a successor state. A fourth report in 2020 might address procedural and miscellaneous issues, and might allow for a first reading of the entire topic. ${ }^{146}$

Protection of the Environment in Relation to Armed Conflicts

\footnotetext{
supra note 139.

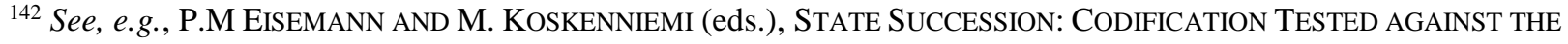
FACTS 193-94 (2000); M.C.R. Craven, The Problem of State Succession and the Identity of States under International Law, 9 E.J.I.L. 142, 148-49 (1998); KRYSTYNA MAREK, IDENTITY AND CONTINUITY OF STATES IN PUBlic INTERNATIONAL LAW 11, 189 (1968); DANIEL PATRICK O’CONNELL, STATE SUCCESSION IN MUNICIPAL LAW AND INTERNATIONAL LAW 482 (1967); J. MÄLKSOO, ILlEGAL ANNEXATION AND STATE CONTINUITY: THE CASE OF THE INCORPORATION OF THE BALTIC STATES BY THE USSR - A STUDY OF THE TENSION BETWEEN Normativity AND POWER IN INTERNATIONAL LAW 257 (2003); A. Cavaglieri, Regles generals du droit de la paix, 26 Collected COURSES OF THE HAGue ACADEMY OF INTERNATIONAL LAW 374, 378, 416 et seq (1929-I); J.P. Monnier, La succession d'Etats en matiere de responsibilite international, 8 ANNUAIRE FRANCAISE DE DROIT INTERNATIONAL 65 (1962); J. Malenovsky, Problemes juridiques lies a la partition de la Tchevoslavaquie, y compris trace de la frontiere, 39 ANNUAIRE FRANCAISE DE DROIT INTERNATIONAL 305, 334 (1993).

${ }^{143}$ See First Report on Succession of States in Respect of State Responsibility, paras. 38-64.

${ }^{144} I d$. at para. 111.

${ }^{145}$ Id. at para. 132.

${ }^{146}$ Id. at para. 133.
} 
While this topic has been on the Commission's agenda since 2013, the prior special rapporteur, Marie G. Jacobsson (Sweden), did not stand for reelection in $2016 .{ }^{147}$ Consequently, the Commission had no report to debate during the sixty-ninth session, and did not engage in any substantive work on this topic. A working group was convened and met on two occasions to consider the work to date and the way forward. ${ }^{148}$ During the last week of the session, the Commission appointed a new special rapporteur, Marja Lehto (Finland), to serve as special rapporteur, ${ }^{149}$ and it is expected that she will produce a first report for the seventieth session.

\section{OTHER DECISIONS AND FUTURE WORK}

During the sixty-ninth session, the Commission placed two new topics on its long-term work program: (1) general principles of law; ${ }^{150}$ and (2) evidence before international courts and tribunals. ${ }^{151}$ During the present quinquennium, the Commission may decide to place one or both topics on its agenda and to appoint special rapporteurs.

In the first part of the seventieth session (May 2018) the Commission will meet, on an exceptional basis, in New York rather than Geneva. The decision to meet in New York for onehalf of one session during the quinquennium was taken based on a view that doing so would allow for greater opportunity for interactions between members of the Commission and representatives of governments to the Sixth Committee (Legal) of the UN General Assembly. Further, during 2018 the Commission is planning to hold events both in New York (May) and in Geneva (July) in celebration of its 70th anniversary.

\footnotetext{
${ }^{147}$ For discussion of prior work on this topic, see Murphy, Sixty-Fifth Session, supra note 70, at 55-56; Murphy, Sixty-Sixth Session, supra note 70, at 143; Murphy, Sixty-Seventh Session, supra note 2, at 838-41; Murphy, SixtyEighth Session, supra note 2, at 731-32.

1482017 Report, supra note 1, at 211, paras. 256-57.

${ }^{149} \mathrm{Id}$. at 212.

${ }^{150}$ Id. at 224-241, Annex A.

${ }^{151}$ Id. at 242-55, Annex B.
} 